\title{
Original Article \\ A CASE CONTROL STUDY ON SELECTED MATERNAL RISK FACTORS OF MOLAR PREGNANCY
}

\author{
Mst. Afroza Khatun', Amina Khatun ${ }^{2}$, Abul Masud Md. Nurul Karim ${ }^{3}$
}

\begin{abstract}
Background: The incidence of gestational trophoblastic disease varies dramatically in different regions of the world. While there are some geographical and racial variations, perhaps a higher incidence in Africa and Asia. The high incidence of molar pregnancy in some populations have been attributed to nutritional and socioeconomic factors. Some maternal biological factors also associated with molar pregnancy. This study aims to explore the various maternal risk factors associated with molar pregnancy.
\end{abstract}

Methods: This case control study was carried out among 50 molar and 100 non-molar pregnant mothers admitted at in patient department of obstetrics and gynecology, Rajshahi Medical College Hospital from January to December 2011. The patients of molar pregnancies were selected on the basis of clinically diagnosed confirmed by ultrasonogram and histopathological examination. Controls group were selected as pregnant women of $1^{\text {st }} \& 2^{\text {nd }}$ trimester. With the ethical approval from the institutional review board (IRB), patients were selected after taking their written consent. A structured questionnaire and a check list were designed with considering all the variables of interest.

Results: Out of 50 cases $48 \%$ belongs to the age group below 20 years, $17 \%$ belongs to the age group above 34 years. $88 \%$ of the control groups are belongs to the age group 20-34 years. Out of 50 cases $4 \%$ had history of prior molar pregnancy, none of the control groups had prior history of mole. $46 \%$ of molar cases belongs to the blood group A, $82 \%$ in case group and $86 \%$ of control group were hormonal contraceptive users. Among the socio-demographic risk factors occupation, education, socioeconomic condition, nutritional status of the case and control group were included.

Conclusion: Molar pregnancy largely remains as etiologic dilemma. No pregnancy is immune to develop as hydatidiform mole. As the risk factors for the disease are unclear, an attempt has been made to identify some risk factors of molar pregnancy to compare them with normal pregnancy to find out any modifiable factors.

JOPSOM 2020; 39(2): 34-39

https://doi.org/10.3329/jopsom.v39i2.53163

Keywords: Molar pregnancy, Maternal, Risk factors, Biological, Socio-demographic.

1. Assistant Professor, Obstetrics \& Gynaecology Rajshahi Medical College.

2. Amina Khatun, Assistant Professor, Obstetrics \& Gynaecology Rajshahi Medical College.

3. Assistant Professor, Community Medicine, NIPSOM, Mohakhali.

Correspondence: Dr. Mst. Afroza Khatun, Email:aminamasud17@gmail.com

\section{INTRODUCTION}

The incidence of gestational trophoblastic disease (GTD) varies dramatically in different regions of the world. In Europe and North America trophoblastic disease complicates 1 in every 2000-3000 pregnancies. The incidence is as high as 1 in 200-300 live births in South East Asia ${ }^{1}$. Molar pregnancy is a pathological condition and has adverse effects on women's health ${ }^{2,3}$. In our country, molar pregnancy is not an uncommon event, but is one of the important causes of maternal death. GTD consist of a group of neoplastic disorders arising from placental trophoblastic tissue after normal or abnormal fertilization. The WHO classification of
GTD includes hydatidiform mole, invasive mole, choriocarcinoma and placental site trophoblastic tumor. Although maternal age, parity, geographical location, ethnicity, low socioeconomic condition, history of oral contraceptive use, previous history of hydatidiform mole, history of abortion, blood group, radiation and artificial insemination have been suggested as risk factors little is known about its etiology $\mathrm{y}^{4-7}$. There are few studies about the relationship between molar pregnancy and husband's occupation which involves contact with soil and dust ${ }^{8}$. The occurrence of a trophoblastic tumor can be regarded as the result of breakdown in delicate host invader balance. There are also reports of matching leukocyte HLA types between the women and her 
partner $^{1}$. Women with a history of one hydatidiform mole have 20 -fold risk of recurrence ${ }^{8,9}$. The risk of persistent trophoblastic disease following hydatidiform mole is about $15-20 \%$. The chance of choriocarcinoma following hydatidiform mole is about $2-10 \%$. The risk of recurrence of molar pregnancy is about $1-4 \%$. There is $1-2 \%$ risk of recurrence of GTD following one molar pregnancy and $25 \%$ following two molar pregnancie ${ }^{6}$. Though exact cause is not known, association of mentioned factors with molar pregnancy is not analyzed in our country. Considering the multidimensional effect of molar pregnancy on women's health as well as the impending choriocarcinoma, this study was done to find to find out the risk factors of molar pregnancy in the context of our country. So, this study was designed to analyze the risk factors, early detection and prevention of its graves sequlae.

\section{METHODS}

This case control study was carried out in obstetrics and gynecology department of Rajshahi Medical College Hospital from January to December 2011. Purposive sampling technique was followed in this study. Molar and non-molar pregnant mother of $1^{\text {st }}$ and $2^{\text {nd }}$ trimester admitted in the Gynaecology department were the study population. In this study, the number of cases were 50 and the control were 100. The patient of molar pregnancy diagnosed clinically, ultrasonography, HCG reports and by histological examination. Cases of choriocarcinoma excluded. The data were collected in a preformed standard data collection sheet form after taking written informed consent of the patients. Data were analyzed with the help of SPSS software program. Descriptive statistics such as mean, median, and SD were calculated. Chi-square test was done to find out the association of selected maternal risk factors with molar pregnancy. Ethical clearance from the Ethical Review Board of Rajshahi Medical College was taken to carry out the study.

\section{RESULTS}

For this case control study 50 molar cases and 100 nonmolar pregnancies were taken as control group. Risk factors were described by some biological variables and also by some socio-demographical variables.

Table I showed that in case group women with age $<20$ years and $>34$ years were in higher and control group women with age 20-34 years were in higher than others. The mean \pm SD in case and control were $25.66 \pm 8.7$ and $24.77 \pm 4.04$ respectively.

TABLE-1: Distribution of mothers by age

\begin{tabular}{|c|c|c|}
\hline \multirow{2}{*}{ Age } & $\begin{array}{c}\text { Case-50 } \\
\text { Frequency } \\
\text { (Percent) } \\
\mathbf{N}(\%)\end{array}$ & $\begin{array}{c}\text { Control-100 } \\
\text { Frequency } \\
\text { (Percent) } \\
\mathbf{N}(\%)\end{array}$ \\
\hline$<20$ years & $24(48 \%)$ & $10(10 \%)$ \\
\hline $20-34$ years & $09(18 \%)$ & $88(88 \%)$ \\
\hline$>34$ years & $17(34 \%)$ & $02(02 \%)$ \\
\hline Mean \pm SD & $25.66 \pm 8.7$ & $24.77 \pm 4.04$ \\
\hline
\end{tabular}

Table II showed in case group there was higher incidence of molar pregnancy in extreme of age, it was $70.6 \%$ in $<20$ years and $89.5 \%$ in $>34$ years. In control group $90.7 \%$ were from 20-34 years. The relationship between age and molar pregnancy was statistically significant $(\mathrm{p}<.001)$. 
TABLE-II: Relationship between age and molar pregnancy

\begin{tabular}{|c|c|c|c|}
\hline \multirow{2}{*}{ Age } & $\begin{array}{c}\text { Case } \\
(\text { Molar })\end{array}$ & $\begin{array}{c}\text { Control } \\
(\text { Non-molar })\end{array}$ & $\begin{array}{c}\text { Total } \\
\text { N (\%) }\end{array}$ \\
\hline N (\%) & $\mathbf{N}(\%)$ & $34(22.67 \%)$ \\
\hline 20 -34 years & $09(9.3 \%)$ & $10(29.40 \%)$ & $97(64.67 \%)$ \\
\hline$>34$ years & $17(89.50 \%)$ & $88(90.70 \%)$ & $19(12.66 \%)$ \\
\hline Total N(\%) & $50(33.33 \%)$ & $02(10.5 \%)$ & $150(100 \%)$ \\
\hline
\end{tabular}

Chi-Square value $\left(x^{2}\right)=73.44 ; \mathrm{df}=2$ and $\mathrm{P}=0.000$

Table III showed that incidence of molar pregnancy higher in nullipara and para 3 or more. The relationship between parity and molar pregnancy statistically significant $(\mathrm{p}<.001)$.

TABLE-III: Relationship between parity and molar pregnancy

\begin{tabular}{|c|c|c|c|}
\hline Parity of the mother & $\begin{array}{c}\text { Case } \\
\mathbf{N}(\%)\end{array}$ & $\begin{array}{c}\text { Control } \\
\mathbf{N}(\%)\end{array}$ & $\begin{array}{c}\text { Total } \\
\mathbf{N}(\%)\end{array}$ \\
\hline Nullipara & $24(80 \%)$ & $06(20 \%)$ & $30(20 \%)$ \\
\hline Para(1or2) & $12(12 \%)$ & $88(88 \%)$ & $100(66.67 \%)$ \\
\hline Para 3or more & $14(70 \%)$ & $06(30 \%)$ & $20(13.33 \%)$ \\
\hline Total N(\%) & $50(33 \%)$ & $100(100 \%)$ & $150(100 \%)$ \\
\hline
\end{tabular}

$\chi^{2}=61.98 ; \mathrm{df}=2 ; \mathrm{P}=.000$

Table IV showed that 12 molar cases had past history of history of mole $(\mathrm{p}<.001)$. molar pregnancy. None of the control group had past

TABLE-IV: Relationship between past \& recent molar pregnancy

\begin{tabular}{|c|c|c|c|}
\hline Past history of mole & $\begin{array}{c}\text { Case } \\
\mathbf{N}(\%)\end{array}$ & $\begin{array}{c}\text { Control } \\
\mathbf{N}(\%)\end{array}$ & $\begin{array}{c}\text { Total } \\
\mathbf{N}(\%)\end{array}$ \\
\hline Yes & $12(100 \%)$ & $0(0 \%)$ & $12(8 \%)$ \\
\hline No & $38(27.5 \%)$ & $100(72.5 \%)$ & $138(92 \%)$ \\
\hline Total N(\%) & $50(33.3 \%)$ & $100(66.7 \%)$ & $150(100 \%)$ \\
\hline
\end{tabular}

$\chi^{2}=26.08 ; \mathrm{df}=1 ; \mathrm{P}=.000$ 
Table $\mathrm{V}$ showed that women of blood group $\mathrm{A}$ and $\mathrm{AB}$ had higher association with molar pregnancy $48.9 \%$ and

$57.6 \%$ respectively $(\mathrm{p}<.001)$.

TABLE-V: Relationship between blood group of mother and molar pregnancy

\begin{tabular}{|c|c|c|c|}
\hline Blood group & $\begin{array}{c}\text { Case } \\
\mathbf{N}(\%)\end{array}$ & $\begin{array}{c}\text { Control } \\
\mathbf{N}(\%)\end{array}$ & $\begin{array}{c}\text { Total } \\
\mathbf{N}(\%)\end{array}$ \\
\hline 'O' & $2(5 \%)$ & $38(95 \%)$ & $40(26.67 \%)$ \\
\hline 'A' & $23(48.9 \%)$ & $24(51.1 \%)$ & $30(20 \%)$ \\
\hline 'B' & $6(20 \%)$ & $24(80 \%)$ & $30(20 \%)$ \\
\hline 'AB' & $19(57.6 \%)$ & $14(42.4 \%)$ & $33(22 \%)$ \\
\hline Total $\mathrm{N}(\%)$ & $50(33.3 \%)$ & $100(66.7 \%)$ & $150(100 \%)$ \\
\hline$\chi^{2}=30.73 ; d f=3 ; \mathrm{p}=.000$ & & & \\
\hline
\end{tabular}

Table VI revealed association of hormonal contraceptive users with case (molar) and control (nonmolar) groups are $32.3 \%$ and $39.1 \%$ respectively. The

relationship between hormonal contraceptive users and molar pregnancy were not significant $(\mathrm{p}>.001)$.

TABLE-VI: Association of molar pregnancy with hormonal contraceptive users

\begin{tabular}{|c|c|c|c|}
\hline Contraceptives & $\begin{array}{c}\text { Case } \\
\mathbf{N}(\%)\end{array}$ & $\begin{array}{c}\text { Control } \\
\mathbf{N}(\%)\end{array}$ & $\begin{array}{c}\text { Total } \\
\mathbf{N}(\%)\end{array}$ \\
\hline Users & $41(32.3 \%)$ & $86(67.7 \%)$ & $127(84.67 \%)$ \\
\hline Non users & $09(39.1 \%)$ & $14(60.9 \%)$ & $23(15.3 \%)$ \\
\hline Total(\%) & $50(33.3 \%)$ & $100(66.7 \%)$ & $150(100 \%)$ \\
\hline
\end{tabular}

$\chi^{2}=0.41 ; d f=1$ and $\mathrm{P}=.339$

Table VII showed $72.7 \%$ mothers of primary level and $57.9 \%$ mothers of illiterate group had relationship with

molar pregnancy which were statistically significant $(\mathrm{p}<.001)$.

TABLE-VII: Relationship between education of mothers and molar pregnancy

\begin{tabular}{|c|c|c|c|}
\hline Education & $\begin{array}{c}\text { Case } \\
\mathbf{N}(\%)\end{array}$ & $\begin{array}{c}\text { Control } \\
\mathbf{N}(\%)\end{array}$ & $\begin{array}{c}\text { Total } \\
\mathbf{N}(\%)\end{array}$ \\
\hline Illiterate & $11(57.9 \%)$ & $8(42.1 \%)$ & $19(12.67 \%)$ \\
\hline Primary & $32(72.7 \%)$ & $12(27.3 \%)$ & $44(29.3 \%)$ \\
\hline Secondary 0r above & $7(8 \%)$ & $80(92 \%)$ & $87(58 \%)$ \\
\hline Total (\%) & $50(33.3 \%)$ & $100(66.7 \%)$ & $150(100 \%)$ \\
\hline
\end{tabular}

$\chi^{2}=60.92 ; d f=2 ; \mathrm{P}=.000$ 
Table VIII showed $67.7 \%$ mothers of poor social class had a relationship with molar pregnancy which was statistically significant $(\mathrm{P}<.001)$.

Table-VIII: Relationship between socio-economic condition (monthly income) and molar pregnancy

\begin{tabular}{|c|c|c|c|}
\hline Socio-economic condition & $\begin{array}{c}\text { Case } \\
\mathbf{N}(\%)\end{array}$ & $\begin{array}{c}\text { Control } \\
\text { N (\%) }\end{array}$ & $\begin{array}{l}\text { Total } \\
\text { N (\%) }\end{array}$ \\
\hline Poor & $42(67.7 \%)$ & $20(32.3 \%)$ & $62(41.33 \%)$ \\
\hline Middle class & $7(9.6 \%)$ & $66(90.4 \%)$ & $73(48.67 \%)$ \\
\hline Higher class & $1(6.7 \%)$ & $14(93.3 \%)$ & $15(10.0 \%)$ \\
\hline Total N(\%) & $50(33.3 \%)$ & $100(66.7 \%)$ & $150(100 \%)$ \\
\hline
\end{tabular}

\section{DISCUSSION}

The incidence of molar pregnancy is now gradually increasing. The prognosis of the disease varies with specific biological and socio demographic factors as well as treatment regimen and compliance to follow up.

In this study, in case group women with age $<20$ years and $>34$ years were significantly higher $(\mathrm{P}<0.05)$ compared to control group which correlates with Parazzini $\mathrm{F}$ et al ${ }^{11}$ and the study in Abu Dhabi ${ }^{12}$.

In this study in case group nullipara or para 2 or more were significantly higher $(\mathrm{P}<.05)$ compared to control group which indicates that in these mothers' $1^{\text {st }}$ pregnancy in nullipara or any pregnancy in para 2 or more ended in GTD which support the statement of a retrospective study of 455 patients of the Royal college Hospital ${ }^{13}$.

Regarding history of previous molar pregnancy, this study showed that in case group 2.8\% mothers had the previous history of mole compared to $0 \%$ in controls which supported by Bracken MB, an epidemiologic review ${ }^{14}$.

In this study $72 \%$ cases and $16 \%$ controls had the history of abortion. Parazzini $\mathrm{F}$ et al reported that the risk factor for molar pregnancy increased with two or more miscarriage ${ }^{15}$

Genetic aspects were also considered through the analysis of blood group of cases and controls. In this study, $46 \%$ cases had blood group 'A' and $38 \%$ cases had blood group "AB" which were supported by a study in Italy ${ }^{11}$.
There was no significant ( $p>0.05)$ association of molar pregnancy with hormonal contraceptive users. This study differs with 'A case control study of Shimuzi $\mathrm{T}^{16}$. Recent use of OCP was found to be unrelated to risk of developing hydatidiform mole ${ }^{14}$. This study has similarity with the present study.

Illiterate and primary level educated women were significantly $(\mathrm{P}<0.001)$ higher in cases compared to control (Table VII). These women knew a little about antenatal care. They were admitted in hospital due to pregnancy complications.

In this study, in case group $86 \%$ were poor and in control group $66 \%$ were of middle class, mothers of poor socioeconomic condition had a relationship with molar pregnancy $(\mathrm{P}<0.001)$. A study in Mexico was done to find out the important etiological factors which showed $22.85 \%$ patients of molar pregnancy were of low social class against $8.57 \%$ of control group suggesting that low socioeconomic condition was a risk factor ${ }^{17}$.

\section{CONCLUSION}

As the disease are unclear, an attempt had been made to identify some risk factors of molar pregnancy to compare them with normal pregnancy and also to find out any rectification possible or not. It must not be forgotten that the prevention or early diagnosis should be the principal goal. Prevention means the suppression of the pathology leading to the disease (molar pregnancy). In this study age $<20$ years, nullipara, illiteracy, malnutrition, blood group $\mathrm{A}$ or $\mathrm{AB}$, past history of molar pregnancy or abortion were found more common among cases than controls. Most of the factors 
are preventable or modifiable. Encouraging later marriage, postponing childbearing up to the age of 20 years will help to reduce the incidence. Nutritional status can be improved by social upgrading and by increasing the level of education. By improving maternal health, we can make a major improvement in the quality of life. Patients with history of spontaneous abortion should be on regular obstetric care which will also help to reduce the occurrence or dreadful complication of molar pregnancy.

\section{REFFERENCES}

1. Jeffcoate's Principle of Gynecology. $7^{\text {th }}$ edition, Jaypee Brothers Medical Publishers (p) LTD, New Delhi, 2008:165.

2. Cunningham FG et al. eds. Williams Obstetrics, $21^{\text {st }}$ ed. New York, Mac Graw-Hill, pp.835-49.

3. Alan H. Decherney, Lauren Nathan, T. Murphy Goodwin, Neri Laufer. $10^{\text {th }}$ edition, Current Diagnosis and Treatment Obstetrics \& Gynecology, Mc Graw Hill companies, New York, 2007:885-889,895.

4. Parazzini F et al. Risk factors for Gestational trophoblastic disease: A separate analysis of complete and partial mole, Obstetrics and Gynecology, 1991; 78(6):1039-45.

5. Parazzini F et al. Reproductive patterns and the risk for gestational trophoblastic disease, American journal of obstetrics and gynecology, 1985;152(7):866-70.

6. Goldstein DP, Berkowitz RS. Gestational trophoblastic neoplasia, clinical principles of diagnosis and management, vol. $4,1^{\text {st }}$ ed. WB Saunders, Philadelphia, 1982:221-32.

7. Michael B Brachen D. incidence and etiology of hydatidiform mole, and epidemiologic review,
British journal of obstetrics and Gynecology, 1087;94:1123-5.

8. Messerli ML. Risk factors for geststional trophoblastic neoplasia. American journal of obststrics and gynecology, 1985;153(3):294-300.

9. D. Keith Edmonds. ed. Dewhart's Textbook of Obstetrics and Gynacology for postgraduates, $6^{\text {th }}$ ed. 1995:71-73.

10. Dutta D C. Textbook of obstetrics, $7^{\text {th }}$ ed, New central book agency, 2011:58, 93, 99, 190, 194.

11. La Veechia $\mathrm{C}$ et al. Risk factors for gestational trophoblastic disease in Itali, Am J Epidemiology, 1985; 121(3):457-64.

12. Graham IH et al. Epidemiological study of complete and partial mole in Abu Dhabi: influence age and ethnic group. $\mathrm{J}$ clin pathol. 1990;43(8):661-4.

13. Olesnicky G, Long AR, et al. Hydatidiform mole in Victoria: etiology and natural history, Aus-NZObstel-Gynecol. 1985;25(1):1-7.

14. Bracken MB. Incidence and etiology of hydatidiform mole, an epidemiological review, BJOG, 1987;94:1123-35.

15. Mazzanti P, La Veechia et al, Frequency of hydatidiform mole in Lombardy, Northern Italy. Gynecol. Oncol. 1986; 24:337-42.

16. Shimuzi T, Yaegashi N. Gestational trophoblastic tumors and recent information, Dept. of Obs. And Gynaecology Tohuko University School of Medicine, Japan, 2002;29(8):1363-70.

17. Quinonez zara C. Hydatidiform mole, clinical aspects, incidence and risk factor, Gynecol. Obst. Mexico, 1995;63:391-94. 